\title{
Turkey's Middle East Policy under the JDP Rule
}

Nuri Yeşilyurt*

Atay Akdevelioğlu**

\begin{abstract}
This article tries to shed light on the root causes of Turkey's activism in the Middle East during the rule of the Justice and Development Party (JDP). By focusing on Turkey's relations with Syria, Iraq, Iran and Israel along with the US foreign policy towards the region, it argues that the transformation of the US Middle East policy is a very important factor that affected Turkey's Middle East policy in the JDP era. Besides, it asserts that recent debates regarding "Turkey's soft power" in the region remind of "Turkey as a model country" discourse since both of them conceives Turkey as a facilitator in the articulation of the Middle East to the global system.
\end{abstract}

\section{Keywords}

Turkish Foreign Policy, Justice and Development Party (JDP), Middle East, Broader Middle East and North Africa Initiative (BMENAI), Soft Power

\footnotetext{
*Nuri Yeşilyurt is a PhD candidate and research fellow in the Department of International Relations, Ankara University, Ankara, Turkey.

**Atay Akdevelioğlu, $\mathrm{PhD}$, is a research fellow in the Department of International Relations, Ankara University, Ankara, Turkey.
} 


\section{Introduction}

It is commonly accepted that along with the Justice and Development Party (JDP) rule in Turkey, a paradigm shift took place in Turkish foreign policy, especially regarding the Middle East. The interpretation of this shift and the role of JDP in it, is an important matter of debate both in the academic literature and Turkish public opinion.

It is important to review how JDP defines its Middle East policy before touching briefly on the opinions which contribute to the academic part of the debate. The Chief Advisor of Turkish Prime Ministry Ahmet Davutoğlu, who is the founder of JDP's foreign policy doctrine and an active name in its practice, has already defined what Turkey's foreign policy towards the Middle East should be in his book Strategic Depth, written even before the rule of the JDP. ${ }^{1}$

According to Davutoğlu, Turkey had a quite narrow-minded vision in the $20^{\text {th }}$ century; back then, Ankara governments were not aware of being the successor of Ottoman heritage, and therefore, they could not appreciate Turkey's potential historical and geopolitical depth. The initial condition for appreciating this potential is getting free from the prejudices against the Middle East, and, mounting a campaign for economic and cultural cooperation with the region. The mindset change, which is required to cancel the security issues out, has to go parallel with this campaign. How-

\footnotetext{
${ }^{1}$ Strategic Depth remains to exist in the list of best selling books in Turkey. The article generated from an interview of Davutoğlu that he gave in January 2008 shows that his views on foreign policy did not change at all and still reflects the baselines of Strategic Depth. Ahmet Davutoğlu, “Turkey's Foreign Policy Vision: An Assessment of 2007”, Insight Turkey, Vol. X, No. 1 (2008), pp. 77-96. Parallelism between Davutoğlu's views on the Middle East policy and the foreign policy principles which were stated in the election proclamation and government program of the JDP could be accepted as an important indicator of the fact that Davutoğlu's views represent the JDP. (Nice Ak Yillara, [AKP Seçim Beyannamesi], Ankara, AKP, 2007, pp. 210-230; “60. AKP Hükümeti Programı", < bttp:/ / wmw.ak.parti.org.tr/programm.doc>, (access date: 30 January 2009).
} 
ever, there is a precondition to viable this change; Turkey has to stop conceiving itself as an ordinary actor in the region and acknowledge its Ottoman heritage. In fact, according to Davutoğlu, this approach is not an option, but a necessity for Turkey. Because, if Turkey does not take an active role in the Middle East, then the Middle East will be active in Turkey. The PKK issue is the very concrete example of this. ${ }^{2}$

Even though Davutoğlu himself has not denominated, due to the special emphasis on the Ottoman legacy, his approach is called as "neo-Ottomanism" in the academic literature. The JDP government has tended to implement this approach effectively, at least in the Middle East.

As it is understood from Davutoğlu's statements summarized above, the JDP has sought to ground its activism in the Middle East on the assertion of having a different world and foreign policy vision from all previous governments. The main implication of this assertion is that the 2002 parliamentary elections had been a breaking point in Turkish history. Because, if the JDP had not come into power in 2002, the existing activism in the Middle East most probably would not have carried in to effect, or, if the JDP had established and come into power earlier, this activism would have initiated earlier as well. In other words; according to this view, the change that the JDP has brought into the foreign policy vision of Turkey constitutes the principal reason of Middle East's increasing significance in Turkey's foreign policy, rather than the international environment and its reflections on Turkey.

Aside from the JDP's own explanations, major views in academic literature that try to interpret Turkey's recent activism in the Middle East can be roughly assessed in three groups according to their causation:

\footnotetext{
${ }^{2}$ Ahmet Davutoğlu, Stratejik Derinlik; Türkiye'nin Uluslararası Konumu, 24th ed., İstanbul, Küre, 2008, pp. 129-142, 247-289, 323-453.
} 
According to the EU centric view, Turkey has been undergoing a transformation towards further stability and democratization as a result of the EU harmonization process. Accordingly; the civil-military relations, perception of national security and the role of the state in the economy are being redefined in Turkey. Therefore, the authoritarian bureaucratic state tradition is being demolished, and instead, there is a civil-democratic state organization being established in accordance with EU criterions. After all, the emerging political structure is inevitably going to develop a more effective and constructive state mentality that takes public demands into consideration both in domestic politics and foreign policy. In these circumstances, the Helsinki Summit of 1999, in which Turkey's EU candidacy was registered, can be taken as the starting point of transformation in Turkish political structure. This means, the transformation that provided the basis for activism in the Middle East was started during the previous government (of Bülent Ecevit) and the JDP government is solely the successor of this process. ${ }^{3}$

The ideology centric view refers to the tension between Kemalists and Islamists, which exists in Turkey since 1920's. Yet in 1990's, the Islamists, who were being represented by the Welfare Party back then, undergone a split off that resulted in Islamists and post-Islamists separation in 2000's. Contrary to its predecessors, the post-Islamist stream -represented by the JDP- did not oppose to EU membership prospects, NATO, and the global capitalism. Moreover, unlike the Kemalists, who take a sensitive and suspicious stand on the subject of national security, post-Islamists were more moderate and democratic. ${ }^{4}$ According to this view, as the representative of the post-Islamist stream, the JDP took over not only the government but also the power from Kemalists in 2000's.

\footnotetext{
${ }^{3}$ Bülent Aras and Rabia Polat Karakaya, "Turkey and the Middle East: Frontiers of the New Geographic Imagination”, Australian Journal of International Affairs, Vol. LXI, No. 4 (December 2007), pp. 471-488.

${ }^{4}$ Philip Robins, "Turkish Foreign Policy Since 2002: between a 'post-Islamist' Government and a Kemalist State", International Affairs, Vol. LXXXIII, No. 1 (2007), pp. 289-304.
} 
The change of power, or, in other words, the dismissal of the Kemalists who have alienated Turkey both from the Middle East and its own culture, removed the outdated obstacles that stands before the Turkish foreign policy, and so, Turkey started to head towards the Middle East as a matter of course. Beyond that, as a model of moderate Islamic government in the Middle East which cooperates with the West, new "Kemalism free" Turkey under the JDP government also has significance in the region. This view concludes that rather than the policies of the JDP per se, the elimination of the Kemalist ideology has enabled Turkey's activism in the Middle East. $^{5}$

According to the security centric view, Turkey's activism in the Middle East under the JDP government is made up of the initiatives which were taken in order to establish a secure environment in the region that was completely destabilized after September 11, and thus, to eliminate the security threats that especially arouse from the developments in Iraq. While doing this, however, unlike the past, Turkey benefits from the advantages of reconciling with its Islamic identity, and acting with a "European" foreign policy vision, which provides it with a stabilizing role in the region. Turkey's growing prominence as a "soft power" in the Middle East, this view suggests, will surely contribute to Turkey's Europeanization and provide a well-founded basis for its relations with the West which have lost their earlier harmony. ${ }^{6}$

The transformation of the US Middle East policy, this article argues, is a very significant factor that was neglected in all aforementioned views and one that must be considered while analyzing Turkey's recent activism in the Middle East. In other words, since the US has placed the region on top of its agenda after September 11, Turkey necessarily turned its face towards the Middle East.

\footnotetext{
${ }^{5}$ Graham E. Fuller, Yeni Türkiye Cumburiyeti; Yükeselen Bölgesel Aktör, trans. Mustafa Acar, 3rd ed., İstanbul, Timaş Yayınları, 2008.

${ }^{6}$ Tarık Oğuzlu, "Middle Easternization of Turkey's Foreign Policy: Does Turkey Dissociate from the West?", Turkish Studies, Vol. IX, No. 1 (March 2009), pp. 3-20.
} 
There are two breaking points which must especially be emphasized while doing such an assessment: 1998 and 2003. In 1998, Turkey started to solve its chronic problems with its neighbors and paved the way for a probable Middle East initiative. By 2003, the conjuncture has become suitable for Turkey to be an active actor in the articulation of the Middle East to the global system. Therefore, in this study, firstly the context of Turkey's relations with its Middle Eastern neighbors before the JDP era will be examined. Then, the transformation of the US policy towards the Middle East in 2000's will be analyzed along with the role of the JDP in this process. Thirdly, Turkey's relations with Israel, Syria, Iraq and Iran, and, its increasing economic and cultural activism throughout the region during the JDP era will be examined in a more detailed manner. Finally, a critique of soft power debates, which has been very popular in recent academic literature, will be presented in order provide a better framework of analysis for Turkey's activism in the Middle East under the rule of the JDP.

\section{Turkey's Relations with Syria, Iran and Iraq before the JDP Era}

By 2002, most of the problems that restricted Turkey's activism in Middle East up until this time had already disappeared. The most important of these problems was the hostile relations with Syria. With the signature of the Adana protocol on 20 October 1998, Syria's support for Kurdistan Workers Party (PKK) came to an end. Bilateral relations proceeded to a new stage when President Ahmet Necdet Sezer paid a visit to Damascus in January 2000 due to the funeral of late Syrian President Hafez Asad. It is noteworthy to mention that Syria, at this stage, eliminated the issues of Euphrates River and Hatay province from its political agenda. Although Syria did not officially retreat its claims about these issues, the problems were postponed without question. In January 2002, the Syrian Chief of Staff paid an official visit to Turkey for the first 
time in history and the two countries signed Military Training Cooperation Agreement. ${ }^{7}$

In 1990's, Turkey's relations with Iran were also unfriendly. The first and the primary problem with Iran was its logistic assistance to PKK. And the other problem was the ideological conflict between the regimes of two countries. The ideological conflict was more related with the endeavors of both regimes to strengthen their legitimacy in the public eye. The policies pursued by Rafsancani and Hatemi decreased this legitimization necessity at least for Iran. As the similar need for Turkey was decreased when the JDP came into the power in 2002, the ideological conflict started to disappear. On the other hand, Iran's support for the PKK was a more serious and persistent problem for bilateral relations. During 1990's Iran, just like Syria, maintained the dialogue of the deaf against Ankara, and hold the PKK as a trump card, as well. ${ }^{8}$ However, 1998 had also been a turning point for Turkish-Iranian relations regarding the PKK issue. Along with Öcalan's expulsion from Syria and his arrest by Turkey in 1999, both the actions of the PKK decreased and PKK-Iran relations deteriorated. This situation led Iran to reconsider its policy towards PKK, and pushed the most important dispute between Turkey and Iran into the background.

The natural gas pipeline project between Turkey and Iran, which was initiated in 1996 despite the US opposition, was finalized and the gas flow started in December 2001. This event not only brought economic results, but also affected the political and

\footnotetext{
${ }^{7}$ Melek Firat and Ömer Kürkçüoğlu, “Arap Devletleriyle İlişkiler, 1990-2001”, Türk Dıs Politikası, Vol. II, ed. Baskın Oran, 8th ed., İletişim Yayınları, İstanbul, 2005, p. 565; Bülent Aras and Hasan Köni, "Turkish-Syrian Relations Revisted”, Arab Studies Quarterly, Vol. XXIV, No. 4 (Fall 2002), p. 55; Meliha Altunış1k and Özlem Tür, "From Distant Neighbors to Partners? Changing Syrian-Turkish Relations", Security Dialogue, Vol. XXXVIII, No. 2 (2006), pp. 229248, 238-239; Turkish Daily News, 19 June 2002.

${ }^{8}$ Atay Akdevelioğlu and Ömer Kürkçüoğlu, “İran’la İlişkiler, 1990-2001”, Türk Dış Politikası, Vol. II, ed. Baskın Oran, 8th ed., İstanbul, İletişim Yayınları, 2005, pp. 579-583.
} 
security relations between the two countries in a positive way. Most particularly, it took on a catalyst role in passing the sponge over the ideological dispute. ${ }^{9}$

Status of Iraq was another problem that restrained Turkey's activism in the region before the JDP era. Since Iraq invaded Kuwait in August 1990, Turkey's relations with this country started to be largely shaped by systemic factors. The existence of Combined Task Force in Turkish territory, and the US bombardment performed frequently within this framework prevented BaghdadAnkara relations to develop in a steady manner. UN sanctions against Iraq were another factor that negatively affected the bilateral relations. Iraq was one of the biggest markets of Turkey before the first Gulf War of 1991; however, the trade embargo imposed on Iraq and the resultant fiscal contraction of Iraq caused Turkey to actually lose this market. Despite Turkey's expectations, Washington did not give it enough elbow room to break this embargo like Jordan. ${ }^{10}$

Although it has lost its authority over the northern part of the country during 1990's, Baghdad protested Turkey's numerous cross border operations against PKK every time. It also tried to bring the issue into the UN agenda from time to time, probably due to its worries about the possibility that Turkey would create a buffer zone in this area and never leave the region again. ${ }^{11}$

In conclusion, by 2002, not only the main problems with Syria which constituted one of the most important obstacles before Turkey's activism in the region, was overcome but also a deepening rapprochement between Damascus and Ankara was triggered in every sense. Relations with Iran were seemed to improve in a similar vein. Only the existence of PKK in Northern Iraq and the future of this country remained as challenges for Turkey in the

\footnotetext{
${ }^{9}$ Akdevelioğlu and Kürkçüoğlu, “İran’la İlişkiler, 1990-2001”, pp. 585-586.

${ }^{10}$ Turkish Daily News, 24 May 2001.

${ }^{11}$ Turkish Daily News, 25 September 2001.
} 
Turkey's Middle East Policy under the JDP Rule

region. And in fact, the main architecture of the JDP's Middle East initiative was established with the US invasion of Iraq in 2003.

\section{The JDP and the Transformation of the US Middle East Policy}

Under the JDP rule, Turkey's relations with Middle Eastern countries flourished rapidly. In this new era, Turkey began to establish a holistic policy towards the Arab/Islamic world. ${ }^{12}$ In order to analyze this shift in the Turkish foreign policy towards the region, the key elements of the US Middle East policy and its transformation in 2000's has to be elaborated in the first place. After that, it will be possible to place the regional activism of the JDP within the framework of the new US Middle East policy.

During the Cold War, US Middle East policy was fundamentally shaped around three purposes, even though methods have changed in course of time. First of these purposes was providing controlling and securing the oil resources in the Persian Gulf; the second one was, ensuring Israel's existence in safe borders and the third one was preventing both the USSR and Arab socialist regimes become strong in the region. ${ }^{13}$ With the end of the Cold War, changes in the regional and global environments have impacted on US policies towards this region too. To begin with, popular resistance in Palestine, which has started to increase with the Intifada in 1987 and raised the sensitivity of world public opinion on the Palestinian issue, endangered the security of Israel. Secondly, Iraq's invasion of Kuwait in 1990 posed a threat to the security of energy resources in the Persian Gulf. Lastly, "rogue

\footnotetext{
${ }^{12}$ For an Arab opinion that claims Turkey, during the JDP era, has started to develop an integrated, multidimensional and autonomous policy towards the Arab-Islamic world, see: Muhammed Nureddin, “Turkiya v'el 'alem el 'arabi.. 'alakat mahsuba”, Assiyase Addevliye, Vol. IVL, No. 169 (July 2007), pp. 182183.

${ }^{13}$ Michael C. Hudson, "The United States in the Middle East", International Relations of the Middle East, ed. Louise Fawcett, Oxford, Oxford University Press, 2005, pp. 285-290.
} 
states" that resisted articulating to the global system and allegedly had the risk of acquiring mass destruction weapons, came into prominence as the new targets of the US in the region.

The US has responded the new threats that emerged in the Middle East during 1990's with a hard security centric approach and brought the "stability" of the authoritarian political regimes in the region to forefront as a precaution against potential turmoil which could arouse in case of democratization attempts. ${ }^{14}$ In this setting, political Islam which has already been on the rise since 1970s, started to come to the fore as the most efficient antisystemic movement in the region. When these developments were combined with permanent military presence of the US in the Persian Gulf after 1991 Gulf War, the activities of radical Islamic movements against the US and its allies in the region increased tremendously. In this sense, 11 September 2001 attacks (9/11) represented both the climax of anti-systemic Islamic movements and the failure of US policy of "stability versus democracy" policy in the region at the same time.

The events of $9 / 11$ had shown the necessity for change in the US Middle East policy. This change has been discussed in a neo-orientalist discourse, according to which the East was not only perceived as a negative projection of the West, but also as a subject which may well pose a threat against the West if necessary measures are not taken. In these circumstances, elimination of the threatening aspects of the East that pose a danger to the West (i.e. the anti-democratic regimes, socio-economic underdevelopment, radical Islamist movements etc.) became a necessity in order to provide the continuity of the international order. ${ }^{15}$ This vision was put into practice by the neoconservative US administration's two-

\footnotetext{
${ }^{14}$ Augustus Richard Norton, "The Puzzle of Political Reform in the Middle East", International Relations of the Middle East, ed. Louise Fawcett, Oxford, Oxford University Press, 2005, p. 136.

${ }^{15}$ Ensar Nişanc1, "Klasik Oryantalizmden Neo-Oryantalizme; İslam, Demokrasi ve Büyük Ortadoğu Projesi Üzerine”, Avrasya Dosyası, Vol. XI, No. 3 (2005), pp. 89-92.
} 
pillar Middle East policy. The first pillar was building a new security architecture in the Middle East through military interventions. And the second pillar was, encouraging neo-liberal transformations in regional countries along with social, economic and political reform attempts that are needed for the establishment of democracy. ${ }^{16}$

The first pillar of this policy would eradicate the irreconcilable regimes, secure the oil resources and serve as a deterrent factor against the regimes that resist to the realization of the second pillar. In this sense, firstly Afghanistan was invaded in 2001 and then Iraq in 2003; a threatening language was adopted against Syria and Iran; NATO's area of activity in the Middle East was enlarged; Israel's aggressive policies against both Palestine and neighboring Arab countries were condoned.

Second pillar became concrete with the Middle East Partnership Initiative (MEPI) that was declared by the US in December 2002 and the Broader Middle East and North Africa Initiative (BMENAI) which was started under the US leadership at the G-8 summit in June 2004. These initiatives were based on Arab Human Development Reports which were prepared under the auspices of the UN Development Program between 2002 and 2005 by outstanding Arab intellectuals. These reports were putting the multidimensional development problems such as the lack of democracy, education, flow of information, and the weakness of private sector at the center of the region's security predicament. ${ }^{17}$ In parallel with these reports, common goal of the aforementioned initiatives was to encourage the neoliberal transformation of the state, society and the economy in the region. In other words, these initiatives were aiming at the integration of the region with the global system within a long-term and high-budget project by encouraging the reforms

\footnotetext{
${ }^{16}$ Hudson, “The United States in the Middle East”, pp. 301-303.

${ }^{17}$ For a critical assessment about the diagnosis and suggestions of these reports, see; Galal Amin, The Illusion of Progress in the Arab World, Cairo, American University in Cairo Press, 2006, pp. 31-61.
} 
on education, politics, economy and the social status of women. ${ }^{18}$ It is for sure that almost all values that were championed in these initiatives such as democracy, freedom, human rights, women's rights, strong civil society and mass education are progressive and positive when they are evaluated out of the context. However, the point here is that these values were belauded (and instrumentalized) for the vital interests of the West, rather than the region itself. Thus, the peoples of the Middle East were turned into the objects that were deprived from their subjectivity and needed to be transformed and tamed.

While supporting the JDP both before and after it took power, the US desired Turkey to play a facilitating role in both pillars of its new Middle East policy. Nevertheless, it can be asserted that the first pillar had priority since the US asked Turkish government to lend troops on her territory before the invasion of Iraq. It is not hard to guess that, if the Turkish Parliament had accepted this demand, Turkey's position in the Arab-Islamic world would have been affected quite negatively and therefore Turkey could not have been able to act as a facilitator in the BMENAI. However, the JDP's failure to put the bill through the parliament on 1 March 2003 had shown the US the limits of using Turkey in the first pillar of its new Middle East policy. ${ }^{19}$ However, straining of US-Turkish relations after the March 1st crisis made JDP leaders worry about being excluded from the restructuring of the Mid-

${ }^{18}$ Haluk Gerger, ABD Ortadoğu Türkiye, İstanbul, Ceylan Yayınları, 2006, pp. 518-531. For detailed information about these attempts, see; US Department of State, "Middle East Partnership Initiative", <http://mepi.state.gov>, (access date: 21 November 2008); US Department of State, "Broader Middle East and North Africa", <http:/ / BMENAI.state.gov>, (access date: 21 November 2008).

${ }^{19}$ The reasons of the bill's rejection in the Parliament could be explained intraJDP dynamics. See, Şaban Kardaş, "Turkey and the Iraqi Crisis: JDP between Identity and Interest", The Emergence of a New Turkey: Democracy and the AK Parti, ed. M. Hakan Yavuz, Utah, University of Utah Press, 2006, pp. 306-330. Turkey's rejection of the bill was interpreted by the Egyptian scholar Ibrahim el Buyumi Ganem as Turkey's unprecedented initiative towards the Arab world. See, Ibrahim el Buyumi Ganem, "El ru'eya el 'arabiya li Turkiya el Jedide”, Assiyase Addevliye, Vol. IVL, No. 169 (July 2007), pp. 187-188. 
dle East. In this setting, the JDP government desired actively taking part in the second pillar of the new US policy, in other words, the transformation process that will integrate the region into the global system in political and economic terms. Thus, on every occasion the JDP circles expressed the necessity for broad reforms in the region and Turkey's possible facilitating role in this process. ${ }^{20}$

The cost of being excluded from the restructuring process of the Middle East, especially in the field of economy, could be quite severe for Turkey. The economy policy of the JDP government was based on the maintenance of the stability program which had been started by the previous government just after the February 2001 economic crisis. Finding new markets for Turkish export products and attracting the foreign capital was important to sustain the stability and economic growth that was generated within the framework of this program. ${ }^{21}$ When the saturation of the European Union and North American markets for Turkey is taken into account, the importance of the Middle East market for Turkish economy is seen better. In the same vein, Turkey aspired to become a prominent address for the Gulf capital which came out of Western markets after the events of September 11.22 Hence, Turkey's possible failure to extend its recent economic opening towards its neighbors to the entire Middle East and thereupon being excluded from the region might have terrible consequences for Turkish economy.

${ }^{20}$ Yeni Şafak, May 29, 2003; Abdullah Gül, “Turkey’s Role in a Changing Middle East Environment”, Mediterranean Quarterly, Vol. XV, No. 1 (Winter 2004), pp. 1-7; Ahmet Davutoğlu, “Ortadoğu’da Çok Kapsamlı Bir Zihniyet Değişimine İhtiyaç Var!”, Genişletilmiş Ortadoğu ve Kuzey Afrika Projesi, November 8-10, 2004 İstanbul Sempozyumu Bildirileri, İstanbul, IKKSV, 2006, pp. 73-83. See also, National Security Council's report that was written in this manner; Gerger, ABD Ortadoğu Türkiye, from p. 538, Milliyet, 19 July 2004.

${ }^{21}$ For the statements of Kemal Derviş about this issue see, Evrensel, 18 October 2003.

${ }^{22}$ For Abdullah Gül's commentary on this issue see, <http:/ / www.ntumsnbc.com/news/247622.asp>, (access date: 18 January 2009). 
US authorities, as a response to the JDP government's eagerness to cooperate with them, accepted to give Turkey an efficient role in the BMENAI. By this way, the US wanted to take advantage of the Turcophilic atmosphere in the Arab World which came about with the rejection of the March 1st bill, and drive world public opinion's attention away from the increasing resistance in Iraq to the "democratization" process of the Middle East. $^{23}$

Turkey's active participation in the BMENAI was confirmed during Prime Minister Recep Tayyip Erdoğan's US visit in June 2005. ${ }^{24}$ Probably until this time, the possible role of Turkey within the scope of the BMENAI was negotiated and bargained between the two sides. In these negotiations, the US had three major expectations from Turkey: Firstly, improving its relations with Israel; secondly, supporting the stability of Northern Iraq, and lastly, participating in the containment and isolation of Iran and Syria. ${ }^{25} \mathrm{At}$ this point, Turkey's relations with these four countries in the following period should be examined in more detail.

\section{Relations with Israel}

The consolidation of Turkish-Israeli ties was the most important condition that had been put forward by the US for Turkey's active participation in the BMENAI. Yet, US officials had increasing concerns in this era about deterioration of TurkishIsraeli relations and had the belief that anti-Semitism was rising in Turkey. ${ }^{26}$ The main developments that caused such concerns can

${ }^{23}$ William Hale, Turkey, the US and Iraq, London, SAQI \& London Middle East Institute at SOAS, 2007, pp. 129-130.

${ }^{24}$ Murat Yetkin, "Büyük Ortadoğu'ya Evet”, Radikal, 9 June 2005.

${ }^{25}$ Robert Olson, "Relations among Turkey, Iraq, Kurdistan-Iraq, the Wider Middle East, and Iran”, Mediterranean Quarterely, Vol. XVII, No. 4 (Fall 2006), p. 23.

${ }^{26}$ For a detailed analysis of US concerns on this issue, see; Robert Olson, "Turkey's Policy toward Kurdistan-Iraq and Iraq: Nationalism, Capitalism, and 
Turkey's Middle East Policy under the JDP Rule

be cited as follows: Ecevit, then the prime minister of Turkey, characterized Israeli policy towards Palestine as "genocide" in April 2002. ${ }^{27}$ In March 2004, Erdoğan defined Israel's assassination policy against Hamas leaders as "state terror". In July 2004, Erdoğan, giving another meeting as an excuse, did not meet Israeli Prime Minister Ehud Olmert who was visiting Turkey. In March 2005, Hitler's anti-Semitist book Mein Kampf became the best seller in Turkey. It was necessary for Turkey to eliminate these concerns and deepen its relations with Israel in order to take an active part in the BMENAI, one of which aims was to soften anti-Western and anti-Israeli feelings in the region.

There were three major reasons for deterioration of TurkishIsrael relations in the first half of 2000's. First of all, Turkey had substantially improved its relations with its neighbors by the end of 1990's and this situation lessened Israel's strategic importance for Turkey. Secondly, Israel has hardened its policy against Palestinians and correspondingly Middle East Peace Process has been interrupted. Under these circumstances, Turkish public opinion's growing sympathy towards the Palestinians made it more problematic for Turkish governments to overtly have good relations with Israel. Lastly, after the invasion of Iraq in 2003, rumors of increasing Israeli activity in Northern Iraq affected Turkish-Israeli relations negatively. ${ }^{28}$

Erdoğan's visit to Israel before his US trip in May 2005 substantially eliminated the problems between the two countries and reinvigorated the relations through a series of new agreements.

State Formation", Mediterranean Quarterely, Vol. XVII, No. 1 (Winter 2006), pp. 53-59.

${ }^{27}$ Due to harsh reactions of Israel and the Jewish community in the US, Ecevit had to say that he was misunderstood. (Turkish Daily News, April 4, 2002; 16 April 2002; 22 September 2002).

${ }^{28}$ Seymour M. Hersh, "Plan B", The New Yorker, 28 June 2004; Yeni Safak, 20 September 2006; for the dissensus between Israel and Turkey on the issues of Iraq and Northern Iraqi Kurds, see; Serhat Erkmen, “1990’lardan Günümüze Türk-İsrail Stratejik İlişkileri”, Uluslararası İlişkiler, Vol. II, No. 7 (Fall 2005), pp. $172-175$. 
Thus, Turkey cleared the most important obstacle in its way to have a part in the reconstruction process of the region under the BMENAI. Both before and during this visit, Turkish and Israeli authorities signed agreements in several areas such as aircraft modernization, missile and drone sale, and military staff exchange. ${ }^{29}$ The first meeting of "Ankara Forum" which aimed at producing common projects to provide a liaison among Israeli, Turkish and Palestinian private sectors was held in April 2005. At this meeting, "Industry for Peace Project" which aims at improving the industrial area in Erez following Israel's retreat from Gaza was brought onto the agenda. ${ }^{30}$ Finally, negotiations related to the Mediterranean Pipeline Project (Medstream) which would carry the oil, gas, water, fiber-optic cables and electricity lines between the two countries, was initiated during this visit. ${ }^{31}$ It is not a coincidence that the number of academic articles which emphasize the importance, continuity and flexibility of Turkish-Israeli relations, has started to increase in this period. ${ }^{32}$

It was for sure that the development of Turkey's relations with Israel at the expense of the Arab world was not desirable for both sides. Therefore, Turkey's scolds against Israel in this period did not cause any serious concerns on both the US and Israeli sides as long as the relations were free of severe problems. Al-

\footnotetext{
${ }^{29}$ Olson, "Turkey's Policy toward Kurdistan-Iraq and Iraq...", p. 60; Radikal, 20 April 2005.

$30<$ bttp:/ / www.tobb.org.tr/haber_arsiv2.php?haberid=279>, (access date: November 21), 2008; Ali Bozçalışkan, “Türkiye Filistin Açılımı”, < http:/ / wnw.genbilim.com/ index.php?option=com_contentertask=viewerid=3852>, (access date: 21 November 2008).

${ }^{31}$ Mete Göknel, “Türkiye ve Akdeniz Boru Hattı, Enerji Güvenliğì,

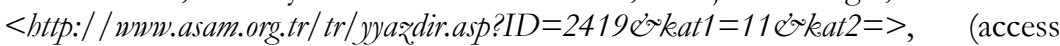
date: 21 November 2008). It is also worth mentioning that the feasibility study of this project was done by Çalık Holding, known for its informal ties with the JDP government. <http:// www.nethaber.com/Ekonomi/69650/Turkiye-ve-Israilarasinda-petrol-dogalgaz-su>, (access date: 21 November 2008).

${ }^{32}$ Joshua Walker, "Turkey and Israel's Relationship in the Middle East", Mediterranean Quarterely, Vol. XVII, No. 4 (Fall 2006), pp. 60-90; Efraim Inbar, "The Resilience of Israeli-Turkish Relations," Israeli Affairs, Vol. XI, No.4 (November 2005), pp. 591-607.
} 
Turkey's Middle East Policy under the JDP Rule

though the senior Hamas officials' visit to Ankara in the wake of Palestinian parliamentary elections in January 2006 seems to be an anti-Israel policy at first glance, Turkey indirectly joined the insulation of Hamas in the secondary process. In this sense, Turkey acted in accordance with Israel by declaring that it would donate 1 million dollars not to Hamas but to Al-Fatah. ${ }^{33}$ Besides, after $\mathrm{Ha}$ mas seized Gaza in June 2007, "Industry for Peace Project" was moved from Gaza to West Bank upon Israel's request. ${ }^{34}$ Likewise, in summer 2006, although the attacks of the Israeli army to Gaza and Lebanon were flayed by Erdoğan, ${ }^{35}$ Turkey, in accordance with Israel's requests, decided to send 1000 soldiers to the UN Interim Force in Lebanon (UNIFIL). ${ }^{36}$ Apart from this, Israel jets' use of Turkish airspace in order to bomb a facility in Northern Syria in October 2007 did not spark any serious reaction on the Turkish side. ${ }^{37}$ During the Israeli Operation Cast Lead against Gaza in December 2008, Erdoğan, despite his harsh statements, rejected the opposition's requests to suspend relations with Israel, saying that he is "not running a grocery store". 38 Finally, in January 2009, Erdoğan stormed out of Davos meeting over a harsh argument with the Israeli President Shimon Peres about the Gaza crisis, but explained in the later press conference that his reaction was to the moderator; and Israeli officials stated that relations would not get harmed. ${ }^{39}$

Consequently, after 2005, it can be argued that there were no important developments that harmed Turkish-Israeli relations

\footnotetext{
${ }^{33}$ Radikal, 06 June 2006.

${ }^{34}$ Sabah, 13 November 2007.

${ }^{35}$ Radikal, 15 July 2006.

${ }^{36}$ Muhammed Nureddin, "Lübnan Kararı ABD İçin", Radikal, 02 September 2006.

37 <http:/ / wnw.bbc.co.uk/turkish/news/story/2007/10/071002_syria_israel.shtml>, (access date: 21 October 2008).

${ }^{38}$ Radikal, 06 January 2009.

39 < bttp:/ / www.ntumsnb.com/ news/473926.asp>, (access date: 31 December 2009); < http:// wnw.bianet.org/bianet/kategori/bianet/112225/erdogan-davosta-gazzepanelini-terk-etti-tepkim-moderatoreydi-dedi?from $=r s s>$, (access date: 31 December 2009).
} 
apart from a number of symbolic statements and visits. Turkish leaders' scolding against Israel created an impression that they are done in an effort to hide the deep bonds between the two countries from both Turkish and Arab public eyes. It is understood that US and Israel were not much disturbed by Erdoğan, with his harsh criticism of Israel, taking the place of Iranian President Mahmoud Ahmadinejad in the eyes of the Arab public, and thus avoiding an Iranian monopoly in the guardianship of the Palestinian cause.

\section{Relations with Syria}

Turkey's friendly relations with Syria became more problematical as the US started to increase its pressure on this country from the second half of 2003 on. In this atmosphere, Syrian President Bashar Assad paid an official visit to Turkey for the first time in January 2004 and Erdoğan's return visit took place in December 2004. During this last visit, a Free Trade Agreement was signed between the two countries along with a number of cooperation agreements in the fields of agriculture and irrigation. ${ }^{40}$ With these agreements, a long step was taken in the settlement of water issue between the two countries. Hence, apart from the technical reasons stemming from both the Euphrates and the Asi, the water issue has fallen off the agenda in both political and legal terms. Hatay issue was also virtually removed from the agenda, even though Syria did not officially relinquish its claims over the province. As for the PKK issue, it had already been solved before the JDP came to power.

Turkish-Syrian relations continued to improve in April 2005 when US pressure on Syria was at its peak with the allegation that Damascus was behind the assassination of the former Lebanese Prime Minister Refik Hariri. Sezer did not change his mind even though US Ambassador to Ankara Eric Edelman criticized the visit. This event clearly showed that there was a disagreement between Turkey and the US regarding the policy towards Syria.

${ }^{40}$ Altunışık and Tür, "From Distant Neighbors to Partners...”, pp. 242, 244-45. 
Turkey's Middle East Policy under the JDP Rule

Shortly after, however, US realized that it could make benefit of Turkish-Syrian rapprochement. For instance, Ahmet Davutoğlu, upon the request of the US, held a consultation with Syrian officials in April 2006 in order to alleviate the crisis in Lebanon. ${ }^{41}$ Another example was that during Erdoğan's Washington visit in October 2006, Bush requested from Erdoğan to use his special relationship with Assad to advise Syria not to resist US policies in Lebanon. ${ }^{42}$

In this era, Turkish policy towards Lebanon has become independent from Syria. Turkish Foreign Minister Abdullah Gül, attending Arab League meeting in Egypt in March 2007 with his status of "guest (observer) state", underlined that Turkey was at equal distance to all Lebanese groups and was not pursuing sectarian policy. ${ }^{43}$ Lastly, during the presidential crisis in Lebanon in 2007, Erdoğan took some initiative and contributed to the solution. ${ }^{44}$ All these events were indication of Turkey's increasing credibility in the eyes of regional states and its active role in the solution of regional crises in accordance with US policies in the region.

As a result of Turkish-Syrian rapprochement, the possibility of Turkish mediation for an Israeli-Syrian peace came to the fore in 2007. Both sides agreed that Turkey should mediate peace talks which had come to a dead end at the end of 1990's. ${ }^{45}$ This mediation attempt, however, should be considered as an effort of Israel and US to solve their problems with Syria by using Turkey, rather than an indication of Turkish influence on Israel.

\footnotetext{
${ }^{41}$ Ruşen Çakır, "Bush İstedi, Davutoğlu Şam’a Gitti”, V atan, 06 July 2006.

${ }^{42}$ Zaman, 02 October 2006.

${ }^{43}$ In this meeting, Turkey gained the support of the Arab League for its candidacy for a 2-year non-permanent seat at the UN Security Council. (Zaman, 03 March 2007 - 05 March 2007).

${ }^{44}$ During the crisis, Erdoğan was, in contact with Damscus, Tehran and prominent politicians in Lebanon like Sinyora and Hariri. President Gül got involved in this shuttle diplomacy with a visit to Damascus in January 2008. (Zaman, 21 November 2007; 22 November 2007; 19 January 2008).

${ }^{45}$ Zaman, 16 January 2007.
} 
Contrary to expectations, Turkish-Syrian relations were not affected by the Israeli bombardment of a Syrian facility by using Turkish airspace in September 2007.46 On the contrary, during Erdoğan's visit to Syria in April 2008, the progress in the mediation process was underlined. ${ }^{47}$ In May 2008, Israeli-Syrian indirect talks started in İstanbul and continued till the Gaza Crisis in December 2008. The US appreciated Turkey's mediation efforts with stating that "this effort of the Turkish government deserves to be applauded". ${ }^{48}$ Thus, Turkey's close relationship with Syria has empowered the formers active role under the framework of the BMENAI rather than being an obstacle to it.

\section{Relations with Iraq}

The most important regional problem that the JDP government inherited from the previous era was the PKK's existence in Northern Iraq and possibility of establishment of a Kurdish state in that region under the leadership of KDP-PUK. With the US invasion of Iraq in 2003, the situation got almost completely out of Turkey's control. The invasion initially enabled Turkey to fill in the authority gap in Northern Iraq that it has been suffering from since 1991. However, early transfer of authority to the Kurds (Erbil government) by the US in the region created a total disappointment in Ankara. Let alone the disputes regarding Erbil's de facto independence, the PKK's expanding existence in the region created an urgent security matter for Turkey. Apart from that, the question of the Kirkuk's status started to occupy Turkey's foreign policy agenda increasingly due to the existence of Turkmens in the city. Turkey, who defends in every international platform that Kir-

\footnotetext{
${ }^{46}$ Syrian Foreign Minister Muallim who came to Ankara soon after the attacks not only accepted Babacan's answer that "he was not informed about the issue", but also did not use any negative statements about the mediation of Turkey. (Zaman, 07 September 2007- 10 September 2007; 28 October 2007).

${ }^{47}$ The main consensus that was reached during the negotiations was declared as Syria's accepting peace in return of Golan Heights. (Zaman, 23 April 2008).

${ }^{48}$ Zaman, 20 May 2008- 02 June 2008.
} 
kuk must remain under the control of Baghdad, clearly expressed its unease with Erbil's de facto control of the city. ${ }^{49}$

In such an environment, the JDP, like its predecessors, was forced to pursue its Iraq policy with a hard security centric vision. This vision was in contradiction with the JDP's general policy in the Middle East and democratization efforts within Turkey. Moreover, while the Iraqi issue started to poison US-Turkish relations which were already problematic since the March 1st Bill, AnkaraBaghdad relations also remained under the shadow of Erbil-PKK connections.

The state of affairs started to change in 2005 with the agreement reached between the US and Turkey regarding the latter's scope of participation in the BMENAI. Thereafter, Turkish policy towards Iraq ceased to be obsessed with the Kurdish issue, and started to contribute to the state formation, stabilization and democratization processes in Baghdad. ${ }^{50}$ In this sense, Turkey supported the constitution building efforts, Jalal Talabani's presidency, government agencies and general elections in Iraq. Besides, İstanbul hosted a meeting between the representatives of Sunni groups and US Ambassador to Baghdad Zalmay Khalilzad on the eve of December 2005 Iraqi elections. Although the meeting did not obtain any concrete results, it showed that Turkey started to contribute to state formation process in Iraq through its influence, though limited, on Sunni groups. ${ }^{51}$ Turkey's another important contribution to the Iraqi central government was the training of Iraqi diplomats and officers. ${ }^{52}$ By supporting the new Iraqi constitution in 2005, Turkey indirectly recognized Kurdistan Regional

\footnotetext{
${ }^{49}$ Foreign Minister Gül told the UN Secretary General Kofi Annan at the an OIC meeting in Jeddah that he was expecting the UN's contributions for preventing the attempts for changing the demographic structure of Kirkuk. ( $\mathrm{Za}$ man, 06 December 2005).

${ }^{50}$ Hale, Turkey, the US and Iraq, pp. 140-151.

${ }^{51}$ Zaman, 05 December 2005- 16 December 2005.

${ }^{52}$ Zaman, 22 May 2005.
} 
Government in Northern Iraq where Turkish businessmen have been very active since 2004.53

US reluctance to take effective action against the PKK in order not to disturb the stability of Northern Iraq was the most important problem for Turkey in Iraq. After 2003, it became a necessity for Turkey to take the approval of the US for cross border operations. But the reluctance of the US to give the approval has caused anger in Turkish public opinion against both the US and Erbil. The JDP government continuously demanded from the US and Erbil for the removal of the PKK elements out of Iraq but has not received an affirmative reply. ${ }^{54}$

In November 2007, the attacks of the PKK and the reaction of Turkish press exceeded the level that the JDP government could face. So, Erdoğan declared a cross border operation plan and received the consent of Iran on this issue. Bush was disturbed of the cooperation between the Iran and Turkey against the PKK and met with Erdoğan in Washington and provided the necessary approval for the operation. ${ }^{55}$ Before the operations which were started with the air attacks in December 2007, Erbil government declared that the city offices of the PKK were closed. The operations of Turkey which continued until March 2008 and which were intended to discharge the PKK from Northern Iraq were so limited but created a relief in the Turkish public opinion and Turkish-

\footnotetext{
${ }^{53}$ For more information about the investments of Turkish businessmen in Northern Iraq, see; Olson, "Relations among Turkey, Iraq, Kurdistan-Iraq, the Wider Middle East, and Iran”, pp. 18-23.

${ }^{54}$ Let alone the liquidation of the PKK from Iraq, the PKK has begun to open offices both in Northern Iraq, Kirkuk and Baghdad. Even in Baghdad a cultural centre was established in the name of Abdullah Öcalan, the founder of PKK. (Zaman, 31 July 2005; 12 July 2006).

${ }^{55}$ Turkey enhanced its interactions with Baghdad as well, and the issue was handled during the Erdoğan-Maliki-Muttaki meeting in November 3. Probably after this point, the US obliged to accept the situation and Bush-Erdoğan meeting took place in November 6. (Zaman, 22 October 2007- 07 November 2007).
} 
US relations. ${ }^{56}$ Although the existence of the PKK in Northern Iraq did not come to an end, diplomatic relationships between Ankara, Erbil and Washington entered a new era. Even the Iraqi President Talabani considered Turkey's operations as a fight against terrorism in Iraq. ${ }^{57}$ Thus, as Turkey undertook a more compromising role in Iraq under the framework of the BMENAI, it was able to obtain the necessary concessions from the US for its cross border operations against the PKK.

\section{Relations with Iran}

The chaotic environment that occurred after the invasion of Iraq started to make Ankara and Tehran get closer. Nevertheless, relations were not free of problems. First of these problems was Iran's subjection to the US containment policy. One of the pillars of this policy was economic and included the prevention of hydrocarbon investments in Iran. The other pillar was composed of political isolation which aimed at changing or transforming the Islamic regime of the country.

Before the JDP era, Turkey had already breached the economic part of the containment by finalizing the natural gas pipeline project with Iran in 2001. ${ }^{58}$ Since the natural gas that flowed into Turkey unbalanced the trade volume between the two countries in favor of Iran, the necessity for providing the balance pushed the JDP government to make a great effort in order to increase exports to Iran. This effort required the two countries to work overtime to figure out how the economic relations between them could be maximized especially in the fields other than energy.

\footnotetext{
${ }^{56}$ During his visit to Washington in January, Gül and Bush evaluated the operation and declared that the US-Turkish cooperation against the PKK will continue. (Zaman, 22 November 2007 - 17 January 2008).

${ }^{57}$ Zaman, 05 February 2008; 08 March 2008.

${ }^{58}$ In addition to this, in July 2007 a new high budgeted energy agreement was signed which authorized Turkey to operate a gas field in Iran and transfer the produced gas. (Zaman, 16 July 2006).
} 
Turkey had significant position in the political part of the containment before the JDP era. Fristly, with its secular regime, Turkey had always constituted an anti-thesis against Iran; and condoned the Iranian opponents such as People's Mujahedin of Iran to use its territory. However, the JDP took Turkey off the political part of the containment as well. It achieved this by ceasing support to the Iranian opponents and not defining the Iranian regime as an element of instability in the region. ${ }^{59}$

The US included the attempts of stopping Iran's nuclear program to the political part of the containment after August 2002. Though the JDP absented itself from this part of the containment, it announced that it would abide by the decisions of the UN on this issue. As a matter of fact, Iran's expectations from Turkey were not more than this. Sometime later, Turkey's possible mediatory role between the US and Iran was mentioned, though never realized. ${ }^{60}$

Another aspect of the containment was Iran's growing influence in the Middle East through the Shiite elements and the US encouragement of Turkey to do the same on the moderate Sunni elements in the region against Iran. Nevertheless, the JDP did not pursue sectarian policies, and thus, was not caught in such kind of a rivalry with Iran.

\footnotetext{
${ }^{59}$ Nevertheless, it was not always easy for Turkey to tolerate some of Iran's ascents, even they remain in rhetoric. For example, while Ahmadinejad's statement that "Israel must be deleted from the world map" got harsh reactions from the West, Turkey's weaker reaction dissatisfied Israel. When Israel conveyed its displeasure and asked Turkey to join the anti-Ahmadinejad campaign, Turkey did nothing more than slightly sharpening its language against Iran. (Zaman, 31 October 2005 - 01 November 2005).

${ }^{60}$ When the possibility of a US air attack against Iran was high, Turkey persistently warned Iran towards making concessions. However, Iran did not step back. For example, in 2006 Gül urgently called up Muttaki and made a "friendly" warning about the serious messages he received from the US. ( $\mathrm{Za}$ man, 07 January 2006).
} 
Second and the most important problem between Turkey and Iran was the PKK issue. By 2003, relations between the PKK and Iran started to shift from cooperation to conflict. In the meantime, however, ongoing problems between Turkey and the US regarding the PKK's activities in Northern Iraq were gradually deepening. As a result of this, Iran not only severed all ties with the PKK, but also classified it as a terrorist organization. Furthermore, Iran started to take concrete actions against the PKK. ${ }^{61}$ As Iran began fighting against the PJAK, the Iranian branch of PKK, its cooperation with Turkey deepened rapidly. Until 2008, Iran tried to take advantage of this situation and took steps that would alienate Turkey from the US on certain issues. ${ }^{62}$

After 2007, along with US and Erbil's concrete steps against the PKK, Iran has also gained a substantial military superiority in its country over the PJAK. ${ }^{63}$ Although it is still not clear whether Iran has completely burnt its bridges with PKK, one can easily argue that during the JDP era the PKK issue has been as a field of cooperation between Turkey and Iran rather than a conflict.

To sum up, the JDP government successfully resisted participating in the containment of Iran despite the insistence of the US, and brought the bilateral relations to its peak after 1979. The most important reason why the US could not push Turkey against Iran was the US authorities' comprehension that a possible interruption of Turkish-Iranian relations would decrease the legitimacy of the JDP both in Turkey and in the region. This is because the

${ }^{61}$ For example, in February 2006, the Iranian police intervened in the protest which was organized in Maku by Iranian Kurds due to the anniversary of Öcalan's arrest, and two protesters were killed during the clashes. (Zaman, 20 February 2006).

${ }^{62}$ For instance, when the US Ambassador to Ankara Wilson declared Turkey's cross border operation against Northern Iraq as “illogical", Iran's Ambassador to Ankara Devletabi declared Iran's full support for them. (Zaman, 18 July 2006).

${ }^{63}$ PJAK's leader Ehkendi was arrested by Iran in May 2008. At the beginning of 2009, the PJAK declared that it is giving up its military struggle against Iran (Zaman, 03 May 2008; 12 January 2009). 
JDP was claiming that its major foreign policy achievement was the improvement of Turkey's relations with its neighbors and the Islamic world in general. Hence, improvement of the relations with Iran -as was the case with Syria- did not prevent Turkey's increasing influence the in the region within the framework of the BMENAI.

\section{Economic and Cultural Activism in the Region}

As a result of 'Turkey's facilitating role in the BMENAI and increasing political activism in the Middle East, there has been a substantial development in its economic and cultural influence on the region.

In economical terms, Turkey's relations with the region developed rapidly throughout the 2000's. The gradual elimination of problems with Iran, Iraq and Syria has triggered Turkey's commercial ties with these countries. ${ }^{64}$ The major obstacle to these economic ties was the US pressure on Turkey to join the isolation of these countries. ${ }^{65}$ The US, however, has gradually come terms with Turkey's growing economic relations with these countries under the framework of its new designs on the Middle East.

Free Trade Agreements (FTA's) were an important indicator of Turkey's growing economic activism in the region. Turkey signed FTA's with many Middle Eastern countries in 2000's and these agreements increased Turkish exports to the region considerably. ${ }^{66}$ Accordingly, the Middle East market became more and

\footnotetext{
${ }^{64}$ Mustafa Aydin and Damla Aras, "Political Conditionality of Economic Relations between Paternalist States: Turkey's Interaction with Iran, Iraq, and Syria", Arab Studies Quareterly, Vol. XXVII, No. 1-2 (Fall-Winter 2005), pp. 2143.

${ }^{65}$ Aydin and Aras, "Political Conditionality of Economic Relations...", p. 36.

${ }^{66}$ FTA's were signed with Israel in 1997, with Morocco, Tunisia, Palestine, Syria in 2004 and with Egypt in 2005. See, Dış Ticaret Müsteşarllğ1 (DTM), "Serbest Ticaret Anlaşmaları", [Undersecretariat of Foreign Trade, "Free Trade Agreements"],
} 
more important for Turkish export products during 2000's. Between 2003 and 2006, 20\% of the trade and industry fairs in which Turkey participated at national level, were held in Middle Eastern countries. This rate increased to $24 \%$ in 2007 and to $29 \%$ in 2008 . $30 \%$ of the fairs in which Turkey plans to participate in 2009, will be held in Middle East countries. ${ }^{67}$ Apart from this, Middle Eastern countries have become the most prominent destinations of Turkish trade delegations that were established with the encouragement of the Turkish Undersecretariat of Foreign Trade. ${ }^{68}$ Besides, joint business councils were established with Syria and Palestine in 2000, with Iraq and Iran in 2001, with Lebanon in 2002, with Saudi Arabia in 2003, with Bahrain and United Arab Emirates in 2005, with Qatar, Kuwait and Oman in 2006, and finally, with Libya and Israel in 2007. ${ }^{69}$

As a result of all these efforts, Turkey's exports to the Middle East and North Africa has increased remarkably starting from 2001 and left the EU, Northern America and Asia behind in terms of rate of increase. Between 2001 and 2007, the share of the region in total exports of Turkey has risen from around 13\% to $24 \%$. Besides, in November 2008, as total exports of Turkey decreased by $17 \%$ due to the global economic crisis, exports to the Middle East have risen by $6 \%$. Finally, between January and November

<http:/ / mwn.dtm.gov.tr/dtmweb/index.cfm?action=detaydyayinID $=341$ \&icerik.ID $=3$ $63 \dot{\sigma} d i l=T R>$, (access date: 01 November 2008).

${ }^{67}$ The statistics were compiled from the data in: DTM, "Fuarlar ve Heyetler", [Undersecretariat of Foreign Trade, "Exhibitions and Delegations], $<$ bttp:/ / mww.dtm.gov.tr/dtmweb/index.cfm?action = detay\&yayinID $=1341$ \&icerikID $=$ $1455 \& d i l=T R>$, (access date: 21 November 2008).

${ }^{68}$ DTM, "Fuarlar ve Heyetler", [Undersecretariat of Foreign Trade, "Exhibitions and Delegations], <http:/ / www.dtm.gov.tr/dtmweb/index.cfm?action=detay \&yayinID $=1341$ \&icerikID $=$ $1455 \& d i l=T R>$, (access date: 21 November 2008).

${ }^{69}$ Works councils with Egypt and Jordan were established during 1990's. For detailed information about the Works councils, see; DEIK, <bttp:/ / wmw.deik.org.tr>, (access date: 21 November 2008). 
2008, the United Arab Emirates, with a total amount of 7.6 billion dollars, became Turkey's third biggest export. ${ }^{70}$

Another important dimension of Turkey's economic relations with the region was Foreign Direct Investments (FDI's). After a legal regulation in 2003 which simplified the entrance of the FDI's into the country, Turkey made several political attempts in order to attract the Gulf capital which did not show a remarkable interest in Turkish market until 2005. ${ }^{71}$ In 2005, however, the amount of the FDI's from the Gulf reached 1.7 billion dollars with an increase rate of $3795 \% .{ }^{72} \mathrm{It}$ is not a coincidence that in the very same year, Turkey agreed with the US to play an effective role in the BMENAI. In this respect, it can be argued that the flow of Gulf capital into Turkey was encouraged by the US.

Turkey's cultural relations with the Middle East also developed considerably during 2000's. The most important indicator of this development was the cultural exchange agreements signed between Turkey and several Middle East countries. Thanks to these agreements which were signed with Yemen, Egypt and Tunisia in 2001, with Syria in 2002, with Palestine in 2005, with Jordan, Israel and Iran in 2006 and with Kuwait in 2007, Turkey's cooperation with the abovementiones countries developed rapidly in the fields of culture, education and tourism. ${ }^{73}$ Besides, the Turkish

\footnotetext{
${ }^{70}$ The statistics in question were compiled from the data mentioned above: DTM, "Dış Ticaret İstatistikleri" [Undersecretariat of Foreign Trade, Foreign Trade Statistics], <http:/ / www.dtm.gov.tr/dtmweb/index.cfm?action=detayrk \&yayinID $=1116$ \&icerikI $D=1225$ \&dil=TR $>$, (access date: 21 November 2008).

71 <http://mww.ntumsnbc.com/news/247622.asp>, (access date: November 21, 2008); Radikal, 07 November 2005.

${ }^{72}$ Uluslararası Doğrudan Yatırmlar Verileri Bülteni, Hazine Müsteşarlığı [International Direct Investments Information Bulletin, Undersecretariat of Treasury], November 2008, p. 15.

${ }^{73}$ Kültür ve Turizm Bakanlığı, "Yürürlükte Olan Kültür Anlaşmaları, Kültürel Değişim Programları ve Mutabakat Zaptları”, [Ministry of Culture and Tourism, "Current Cultural Agreements, Cultural Exchange Programs and Memorandums of Understanding"'],
} 
Ministry of Culture and Tourism organized special campaigns for the advertisement of Turkey in the Middle East. Apart from this, increasing popularity of Turkish soap operas such as Gümüs, Iblamurlar Altinda etc. in the Arab world have made an important contribution to the prestige of Turkey in the region while enabling another form of cultural interaction between the two sides. ${ }^{74}$ The Ministry of Culture and Tourism also realized this fact and started negotiations with Turkish soap opera actress Tuba Büyüküstün and the Saudi MBC channel, on which Turkish soap operas were frequently broadcasted, for the tourism campaign of Turkey in $2009 .{ }^{75}$

Finally, as for the tourism, after a decrease in the second half of 1990's, the number of tourists visiting Turkey from the Middle Eastern countries reached above 1 million with an increase rate of $25 \%$ in 2000. Since then, the number of Middle Eastern visitors have risen progressively and reached 2.5 million in 2007. More than 1 million of these visitors were coming from Iran. ${ }^{76}$ With this tremendous increase in the number of Arab visitors to Turkey, some Arab commentators started to claim that İstanbul took the place of Beirut as the top Arab tourism destination. ${ }^{77}$

\section{Conclusion: Turkey's Soft Power in the Middle East}

It is a matter of fact that Turkey's recent activism in the Middle East affected its image in the region positively. This situation is corroborated by three images of Turkey that has become

<http:/ / disiliskiler.kulturturizm.gov.tr/BelgeGoster.aspx?F6E10F8892433CFFA809 88BFAA5E6B09B39AF7D896DAF648>, (access date: November 21, 2008).

${ }^{74}$ Zaman, 27 May 2008.

${ }^{75}$ Hürriyet, 26 November 2008; Milliyet, 14 September 2008.

${ }^{76}$ Kültür ve Turizm Bakanlığı, "Sınır Giriş-Çıkış İstatistikleri” [Ministry of Culture and Tourism, "Border Statistics: Number of Arriving-Departing Foreigners and Citizens"],

<bttp:/ / mww.kultur.gov.tr/TR/BelgeGoster.aspx?F6E10F8892433CFF2B81939FD 5B60AFAFFDE13C621852F44>, (access date: 21 November 2008).

${ }^{77}$ Muhammed Nureddin, “Turizmde İstanbul Beyrut'un Yerini Aldı”, Zaman, 23 August 2005. 
prominent in the Arab world: First of these is the image of Turkey as a democratic country in which a political party rooted in political Islam could come into power with free and fair elections. The second is the image of Turkey as an economic success story. And the third is the image of Turkey as a country that has the potential to be the representative of the Islamic world in the West. ${ }^{78}$

In parallel with Turkey's becoming a "centre of attraction" in the Arab world, the debates on its "soft power" in the region has shown a significant increase in the academic literature. ${ }^{79}$ Soft power, in the abstract, is a state's ability to manipulate the behaviors of others through influencing their desires and aspirations by means of the legitimacy of its culture, values and policies. A state with "soft power" becomes a "centre of attraction" with its values, getting others to admire these values and therefore ultimately making them behave in favor of its own interests. ${ }^{80}$ This term was propounded in late 1980's, at a time when the US hegemony was in question, in order to emphasize that the global dominance of the

\footnotetext{
${ }^{78}$ For Arabic views on these issues, see; Mohamed Sid-Ahmed, "Turkey's new experiment," Al-Ahram Weekly, November 14-20, 2002; İbrahim El Beyumi Ganem, "Türk hükümeti ile bizim hükümet," Zaman, 03 November 2008; Ganem, "El ru'eya el 'arabiya...", pp. 187-189; Nureddin, “Turkiya v’el 'alem el 'arabi...”, pp. 183-184; Zeynep Dağ1, “Ortadoğu Perspektifinden Türkiye’nin Avrupa Entegrasyonu: “Öteki'leşme aş1llyor mu?” AK Partili Yillar, comp. Zeynep Dağ1, Orion, İstanbul, 2006, pp. 167-188.

${ }^{79}$ Phar Kim Beng, "Turkey's Potential as a Soft Power, A Call for Conceptual Clarity”, Insight Turkey, Vol. X, No. 2 (2008), pp. 21-40; Hakan Altnay, “Turkey’s Soft Power: An Unpolished Gem or an Elusive Mirage", Insight Turkey, Vol. X, No. 2 (2008), pp. 55-66; Meliha Benli Altunış1k, "The Possibilities and Limits of Turkey's Soft Power in the Middle East", Insight Turkey, Vol. X, No. 2 (2008), pp. 41-54; Tarkk Oğuzlu, "Soft Power in Turkish Foreign Policy", Australian Journal of International Affairs, Vol. LXI, No. 1 (March 2007), pp. 81-97; Bülent Aras, "Turkey between Syria and Israel: Turkey's Rising Soft Power”, SETA Policy Brief, No. 15 (May 2005).

${ }^{80}$ Joseph Nye, "Soft Power and American Foreign Policy", Political Science Quarterly, Vol. CXIX, No. 2 (2004), p. 2. For a critique of existing approaches to the concept of power in the academic literature, see; Pinar Bilgin and Berivan Eliş, "Hard Power, Soft Power: Toward a More Realistic Power Analysis", Insight Turkey, Vol. X, No. 2 (2008), pp. 5-21.
} 
US was largely maintained by the "legitimate" values it possessed rather than its military power. ${ }^{81}$

The distinguishing feature of the recent debates about the "soft power" of Turkey in the region is the increasing usage of the term "soft power" instead of "model country". Bu indeed, while speaking of Turkey's soft power, the overtone in these debates is not Turkey's increasing influence and dominance in the region acquired through the values it possessed. Rather, the main point is putting a Muslim country that has relatively succeeded in articulating to the global system through the neoliberal transformation it has been undergoing (Turkey) in front of the other regimes in the region (the Middle East) as a model and encouraging the latter to undergo similar transformations. Thus, the term "soft power" is being used in a similar meaning with the term "model country" in these debates.

To sum up, the JDP government took over a country that had started to improve its relations with its Middle Eastern neighbors and desired to play a complementary role in the articulation of the region to the global system within the context of the BMENAI by the US. And this desire was welcomed by the US. The biggest success of the JDP in this process was that it was able to keep the US encouragement in this policy covert and resisted the restrictions which the US wished to bring in Turkey's relations with Syria and Iran. Turkey's increasing political, economic and cultural activism in the Middle East during 2000's should be read in this manner.

${ }^{81}$ Beng, "Turkey's Potential as a Soft Power, A Call for Conceptual Clarity", p. 30. 